\title{
OSS AND THE DEPARTMENT OF STATE
}

The Swedish-American archaeologist Olov Janse lectures tonight about Indochina to the Royal Academy of Letters, History and Antiquities at the Nordic Museum. During the war, Professor Janse was working with psychological warfare in the United States, and his work primarily concerned Indochina. ${ }^{843}$

Following the capitulation of France in June 1940, a number of faculty members at Harvard University had organized a "defense group". Its purpose was to provide information about the situation in Europe and Asia, and give scholarly support to the war efforts in the United States and among its allies. Before the war ended, the group, officially named "American Defense, Harvard Group", had gathered more than 1,700 members and 240 active volunteers, among whom were Olov and Ronny Janse. They were encouraged to join the group after the attack on Pearl Harbor, about a year after they had returned to Harvard from their last expedition. In addition to practical arrangements to help refugees, and various initiatives to support military morale, the Defense Group pursued tasks that bordered on intelligence service, in the form of translations and analyses of foreign language radio and press reports. With her broad

843.Dagens Nyheter, 8 June 1955: "Indokinaforskare gästar Stockholm”. In the Swedish original: "Den svenskamerikanske arkeologen Olov Janse föreläser i kväll inför Vitterhetsakademien på Nordiska Museet om Indokina. Professor. Janse var under kriget sysselsatt med psykologisk krigföring i US A och främst var det Indokinafrågor som han fick ägna sig åt.” 
language skills, Ronny must have made a significant contribution to the group, which at its peak had thirty-five different languages represented among its members. ${ }^{84}$ Olov joined a sub-section with special focus on cultural heritage: The Committee on the Protection of Monuments. The members of this section had special knowledge of foreign countries and regions affected by the war, and they compiled lists of monuments in need of attention and protection in a situation of war. Greg Bradsher at the US National Archives has studied these lists and describes their overall purpose and format:

The longer lists were prefaced by an introduction outlining the significance of the material in the national and religious sentiment of the country in question, and a short historical outline. Each list was prepared by individuals or groups with special knowledge of the countries concerned, and included material not to be found in guidebooks. Throughout, special care was taken to include material which for any reason was treasured or revered by the local population, quite apart from any general historical or artistic interest. ${ }^{845}$

Olov Janse wrote one such long list: "List of Monuments in INDOCHINA by Olov R.T. Janse" ${ }^{846}$ Following very closely the format sketched by Bradsher, Janse's text gives a culture-historical background to the monuments of Indochina, with strong emphasis on the parts of Annam and Tonkin where he had worked during his three expeditions. He explains the importance of both Buddhism and animism, and he emphasizes that it is pivotal to consider the importance of spirits for the native populations in order to understand any cultural heritage of Indochina. The list of monuments (which includes museums, art collections, private collections, scientific institutions, libraries and archives) is clearly influenced by Janse's own work and travel experiences. It has a strong emphasis on Tonkin and Annam, particularly Hanoi and Thanh Hoa

844.http://oasis.lib.harvard.edu/oasis/deliver/ hua12007

845. "The American Defense, Harvard Group's Committee on the Protection of Monuments", blogpost by Dr Greg Bradsher 28 August 2014, The Text Message Blog. https:// text-message.blogs.archives.gov/2014/08/28/american-defense-harvard/

846. Now kept in Harvard University Archives. Pusey Library-Harvard Yard. Cambridge, Mass., US A. 
with surroundings, while Cochinchina, Cambodia and Laos are treated more superficially.

On Christmas Eve 1942, when Olov Janse had been Visiting Lecturer at Harvard University for two years and a year after they had joined the Defense Group, Kennard Rand, who was at the time Pope Professor of Latin at Harvard, wrote a letter to Professor Harold J. Coolidge at the Office of Strategic Services - a new secret intelligence organization in Washington, DC. Rand wrote that the University would not have any funding to support Janse's position as Visiting Lecturer after 1942, but suggested that he might be useful to the OSS. ${ }^{847}$ Coolidge responded a week later, on 1 January 1943 that he would contact Janse personally, adding: "Experts on Indo-China outside of the missionary field are surprisingly rare." ${ }^{48}$

After a short sojourn as consultant to the Board of Economic Warfare beginning in October 1943, Olov Janse was appointed to a position at the Morale Operations (MO) for OS S in Indochina, while Ronny worked as an OSS biographical analyst. They left Harvard in Cambridge Massachusetts, and moved to Washington, DC, where the OSS headquarters were located in the Old Naval Observatory on 23 rd and E Street. Two years later OSS was dissolved, and in September 1945 they were both transferred to the US Department of State where Olov became Deputy Chief of the South-East Asia section of the Research and Analysis Branch, ${ }^{849}$ and Ronny continued as biographical analyst. ${ }^{850}$

The Office of Strategic Services, which is often referred to as the OSS, is known as the predecessor of the CIA. It had been founded by President Franklin D. Roosevelt in June 1942. It sprung out of a need to have an organized body for international intelligence on US state level, which had not existed prior to the Second World War. The OS S was in many ways the child of one man: William Joseph "Wild Bill" Donovan (18831959) who became its first and only director. Donovan, who has been described as "a Hoover republican, an Irish Catholic, and a millionaire

847.Letter from K. Rand to H. Coolidge, 24 December 1942. National Archives at College Park, MD. Records of the Office of Strategic Services (Record Group 226), Entry 92, Box 197.

848. Letter from H. Coolidge to K. Rand, 1 January 1943. Ibid.

849. NAA: Janse 2001-29; Solheim 1984-85:10.

850. Renée Janse's Personal History Statement, July 1950, NAA: Janse 2001-29. 
Wall Street lawyer", ${ }^{851}$ was "charismatic, intellectually unconventional, a bit chubby, and certainly not elegant, intensely loyal to those loyal to him, and apparently without fear". ${ }^{852} \mathrm{He}$ was a personal friend to the President (although they represented opposite political parties) and had his full support in building the new intelligence organization. Widely travelled and with strong international networks since the First World War and the inter-war years, Donovan found international inspiration for the organization in the British MI6 (also known as the Secret Intelligence Service). ${ }^{85}$ With direct backing from President Roosevelt, Donovan had ample resources and encouraged the development of new creative ways to retrieve, process, analyse, and use intelligence data, at almost any cost. ${ }^{854}$ Hence the OSS is often associated with innovative James-Bond-style methods of espionage, especially among its field agents.

But Wild Bill Donovan was not only a daredevil recruiting fearless young spies and soldiers for extraordinary missions to foreign lands. Above all, it seems, he was a firm believer in the power of academic knowledge and analysis. The historian Robin Winks writes that "he had a high regard for professors, placing them above diplomats, scientists, and 'even lawyers and bankers'; he valued their 'card index' mentality". 855 The foundation for OSS therefore rested on academics from Harvard, Yale, and other Ivy League universities. Most were well-connected, wealthy men with a high level of cultural capital from the US academic, political, and social elite. ${ }^{856}$ An example is Harold Coolidge, who got the letter from Kennard Rand and took the first steps to have Janse involved with the OSS. Harold Jefferson Coolidge (1904-1985), a descendant of Thomas Jefferson, was a zoologist and expert on exotic mammals with degrees from the universities at Harvard and Cambridge, UK. Having participated as an assistant in a zoological expedition to central Africa in his early twenties, at the age of 24 he became leader of the Indochina part of the "Kelley-Roosevelt Asian Expedition for Chicago's Field Museum of Natural History", funded by Theodore Roosevelt's two sons Theo-

851. Smith 2005:1.

852. Winks 1996:64.

853. Smith 2005:24.

854. "Inevitably, activism also meant waste. Donovan procured for OSS an unlimited (and largely unvouchered) budget that ran into the hundreds of millions during the four years of war" (Smith 2005:3).

855. Winks 1996:67; see also Smith 2005:11.

856. Winks 1996. 
dore, Jr and Kermit, who desired to hunt and collect big game such as the giant panda. ${ }^{857}$ After the expedition's successful return to the United States, Coolidge became curator of mammals at Harvard University's Museum of Comparative Zoology, and later became the founding director of the World Wildlife Fund. ${ }^{858}$ Coolidge was in many ways typical of a high-ranking OSS officer. Like Coolidge, many of the men Donovan recruited to high positions in the OSS were young but already with established Ivy League university careers. They were wealthy and well travelled, with family, professional and social networks connecting them to the political elite of the United States.

In addition to the OSS branches that are perhaps most commonly associated with creative and adventurous espionage, such as Secret Intelligence and Special Operations, the OS S had a much broader base back in the United States, and involved as much as 13,000 personnel at its apogee in 1944. It was a hybrid military-civil organization and had branches for Counterespionage, Research \& Development, and units for Field Photography, Communications, Special Funds, and Medical Services. Last but not least were the two branches where Olov Janse worked: Morale Operations (MO) and Research \& Analysis (R\&A). ${ }^{859}$

The Morale Operations (MO) branch was established in January 1943 with the mission to perform psychological warfare, particularly in the form of false propaganda and the spread of rumours. By means of radio broadcasts, letters, postcards, leaflets, and other printed materials, the MO branch produced information and "black" propaganda that was communicated and advertised as if it came from the enemy or resistance movements. The intention was to create a sense of distrust, insecurity and ultimately chaos among enemy forces and civilians. ${ }^{860}$ It was a highly creative task performed mainly by psychologists, writers and other intellectuals. The MO branch was mostly focused on Europe and the Axis powers. As far as we can see, Olov Janse worked for the MO branch for two years, from August 1943 to September 1945. He worked with issues concerning Indochina and the Far East and wrote one MO report with the title Some Methods of Japanese Penetration in French Indochina Previous to

857. Coolidge \& Roosevelt 1933.

858. Sullivan 1985 .

859. Chalou 2002; Smith 2005; Liptak 2009.

860. Liptak 2009:9. 
the $\mathrm{War}^{861}$ almost immediately after he joined the OSS in August 1943. The Research \& Analysis (R\&A) branch, where he was working after the transfer to the State Department in September 1945, appears in many ways to have been a more suitable section for Olov Janse's profile and expertise. The R\&A staff were responsible for finding data (in libraries and archives rather than by adventurous field operations), and selecting, processing, and analysing it to create bodies of information about enemies and foreign cultures that would serve strategic warfare. This task required skilled academics, and real-life experiences of foreign lands such as those Janse had of Indochina were particularly valued. Historians and anthropologists in particular were recruited to the OSS and its R\&A branch. More than twenty university anthropologists, including Gregory Bateson and Cora Du Bois (whom Olov Janse corresponded with), ${ }^{862}$ were working for the organization. ${ }^{863}$ We believe that two reports and one film that Olov Janse produced during his time at OSS were for the R\&A branch. ${ }^{864}$

The work was secret, and it took until October 1945 before Olov mentioned his wartime assignment for the first time in a letter to Birger Nerman. ${ }^{865}$ In the letter, which is the only informal personal record we have from their time at the OSS, he describes how, shortly after the attack on Pearl Harbor, he was urged to join the Harvard Defense Group, ${ }^{866}$ where he dealt with issues concerning "protection and salvage of cultural monuments in the Far East". Janse published a long report on Indochina during his time in the group. ${ }^{867}$ In that capacity he was invited to Washington, DC, as a "temporary consultant of the Federal Government", and after the summer semester 1943 he was recruited to the OSS where

861. OS S R\&A Report No. 1279, by Olov R.T. Janse, 31 August 1943. Original document in National Archives at College Park, MD, USA.

862. Letter from Olov Janse to Cora Du Bois, 25 May 1944. National Archives College Park, MD. Records of the Office of Strategic Services (Record Group 226), Entry 92, Box 197.

863. Price 1998; Price 2008.

864. Janse $1944 ; 1945$.

865. Letter from O. Janse to B. Nerman, 3 October 1945. Riksarkivet. Kartong 4. Korrespondens Brev IV 1942-1946.

866. Formal name: American Defense, Harvard Group. https://hollisarchives.lib.harvard.edu/repositories/4/resources/4139

867. American Defense - Harvard Group. Committee on the protection of Monuments. List of Monuments in Indo-China, by Olov R. T. Janse, Records of American Defense, Harvard Group. Call number 3139, Box 76. 
he worked with issues concerning East Asia, and had "spent much time on cultural problems". At the time of writing he had, "by a letter from President Truman", been transferred to the Department of State, on a temporary mission lasting in the transit period between war and peace. Not being a US citizen, he writes, he would have no chance of turning it into a permanent position. And he concludes:

You must not mention anything about this to the press, but it is alright if you should happen to mention it to H.R.H., or to someone in our closest circle of friends. It has been stimulating to be in Washington during these intensive years. Ronny and I have also been out a lot, and have met many interesting people from every corner of the world. ${ }^{868}$

Olov Janse had evidently not lost the urge to have his activities and achievements known in Sweden, especially among highly influential people like the Crown Prince. We know also that he sent a copy of the anonymous publication Joint Army-Navy Intelligence Study of Indochina: People and Government from 1945 to a library in Stockholm with his name written, in his own hand, on the cover. ${ }^{869}$ Judging from the letter alone, he appears to have enjoyed the years with the intelligence services. Other letters, however, indicate that he hated it and thought of it as a particularly dull and boring period of his professional life. ${ }^{870}$

Because their missions were secret and the OS S archives are restricted, we know very little about what Olov Janse did for the OS S, and even less about Ronny's assignment. Other than his formal titles, which suggest that he was employed in the capacity of expert on East and Southeast Asia, Indochina in particular, we know for certain that he produced one film and three written reports for immediate intelligence purposes.

868. Letter from O. Janse to B. Nerman, 3 October 1945. Riksarkivet. Kartong 4. Korrespondens Brev IV 1942-1946. In the Swedish original: "Du får inte nämna något åt pressen om allt detta, men det är all right om Du händelsevis skulle vilja nämna det för H.K.H. eller till någon inom den allra närmaste vänkretsen. Det har varit spännande att vistas i Washington under dessa händelserika år. Ronny och jag har dessutom varit mycket i farten och träffat många intressanta personer från alla världens hörn.”

869. Janse 1945, attributed copy at the National Library of Sweden (Swe: Kungliga biblioteket), Stockholm (22 A d Fol.)

870.E.g. letter from Olov Janse to Ronny Janse, 9 January 1947. NAA: Janse 2001-29. 


\section{The film}

Setting off on their first expedition to Indochina in 1934, Olov and Ronny Janse brought a new film camera to record their journeys and their work. ${ }^{871}$ The camera was subsequently used throughout their three expeditions to document excavations, particularly when they had VIP delegations visiting the sites, and to make observations of mountain tribes in Tonkin and Annam, and indigenous groups along the coast of Annam. When contracted by the OSS as an expert on Indochina, Janse saw an opportunity to make use of the films. ${ }^{872}$ But the world was no longer the same as it was a decade earlier. The once lavish passenger ships were now used to transport troops and refugees across the seas, if they had not been bombed and sunk. Indochina was under Japanese occupation and the entire world was in turmoil. Hence it was necessary to transform the films in order to reactivate the contents. The OSS had ample resources for new and creative ways to form intelligence knowledge, ${ }^{873}$ which Janse activated to edit parts of films - which had been shot and partly edited as a documentation of a French colonial archaeological and ethnographic enterprise - into an instruction film for US Intelligence purposes. On 1 June 1944, he wrote to Lieut. Ray Kellogg at the OSS Field Photographic Division:

Members of several sections of the OSS and the Navy Department have expressed the desire to have projected here a $16 \mathrm{~m} / \mathrm{m}$ film which I took between 1937-40 in Indochina and the Phil-

871. It is unclear what sort of film camera Janse used and if he used the same camera during his different expeditions. In his autobiography he writes about his Kodak (Janse 1959:83) and one film is introduced with the label Ansco, which was a film-producing company in the US between the mid 1800 s and the 1980 s.

872. The films used at the OS S were shot during the second and third expeditions. The films shot during the first expedition were left in Paris before they set off on the second expedition. In letters to Ronny from Paris during the UNE SCO assignment 1946-47 (Letters from O. Janse to R. Janse, 31 December 1946 and 17 April 1947, NAA: Janse 2001-29) Olov mentions twice that he found a film among their other stored belongings, featuring their trips to Yunnan, excavations at Lach-truong, Bac Ninh, Sam Son, etc. This appears to be the same film that is mentioned in a letter to Johan Gunnar Andersson dated March 1936, where Janse writes that he has a film from his work in Indochina that is ready to be shown, if Andersson would like to see it (Letter from O. Janse to J. G. Andersson, 29 March 1936. Östasiatiska samlingarnas arkiv. Korrespondens 1936 E1A:13, 0300a,b-0301a,b).

873. Smith 2005:3. 
ippine Islands. We expect to have a show in the near future in the Administration Building of the OSS for personnel interested in these regions. Though the film is already provided with some titles, it has been suggested that some additional subtitles would make the film easier to understand, especially with references to various place-names and names of some little known native tribes. We would appreciate very much, indeed, if you would agree to have these additional subtitles made and inserted. ${ }^{874}$

Later the same month, Janse wrote once more to Kellogg:

I wish to express to you our appreciation for the work you have done to improve the SEA films [...] The films have now been shown and it has been suggested that parts of it be copied and sent overseas. For this reason it would be undoubtedly beneficial to our consumers if a few addition titles could be made (a list of which is here enclosed) $[\ldots] \cdot{ }^{875}$

The finished edited film is 23 minutes long and is divided into two parts; the first part with 19 subsections and the second part with 21 subsections. ${ }^{876}$

After the title slide (fig. 65) the first part of the film begins with 55 seconds with the title "Colombo and Mount Lavinia". The section, which was shot in 1936 at the stopover in Ceylon (now Sri Lanka) on their way to Saigon for the second expedition, features streets with traffic police and natives, walking by and standing still, posing for the camera. One segment is of the seaside, shot from the veranda of the Mount Lavinia Hotel. In the water are outrigger canoes, and a native man is fishing with a rod from the rocky shore. A group of people in colonial-style dress, shorts and helmets, socialize and watch the fisherman from the hotel's elevated veranda. The next section is 50 seconds long and titled "The harbour of Colombo". Most of it appears to be shot from the deck of the French passenger ship Maréchal Joffre and features the surrounding water and harbour with boats, cranes, and warehouses. Ronny embarks the ship

874. Letter from O. Janse to Ray Kellogg, 1 June 1944. National Archives at College Park, MD. Records of the Office of Strategic Services (Record Group 226) Entry 90, Box 19. Entry 90, Box 19.

875 . Ibid.

876. Swedish Television Archive. 


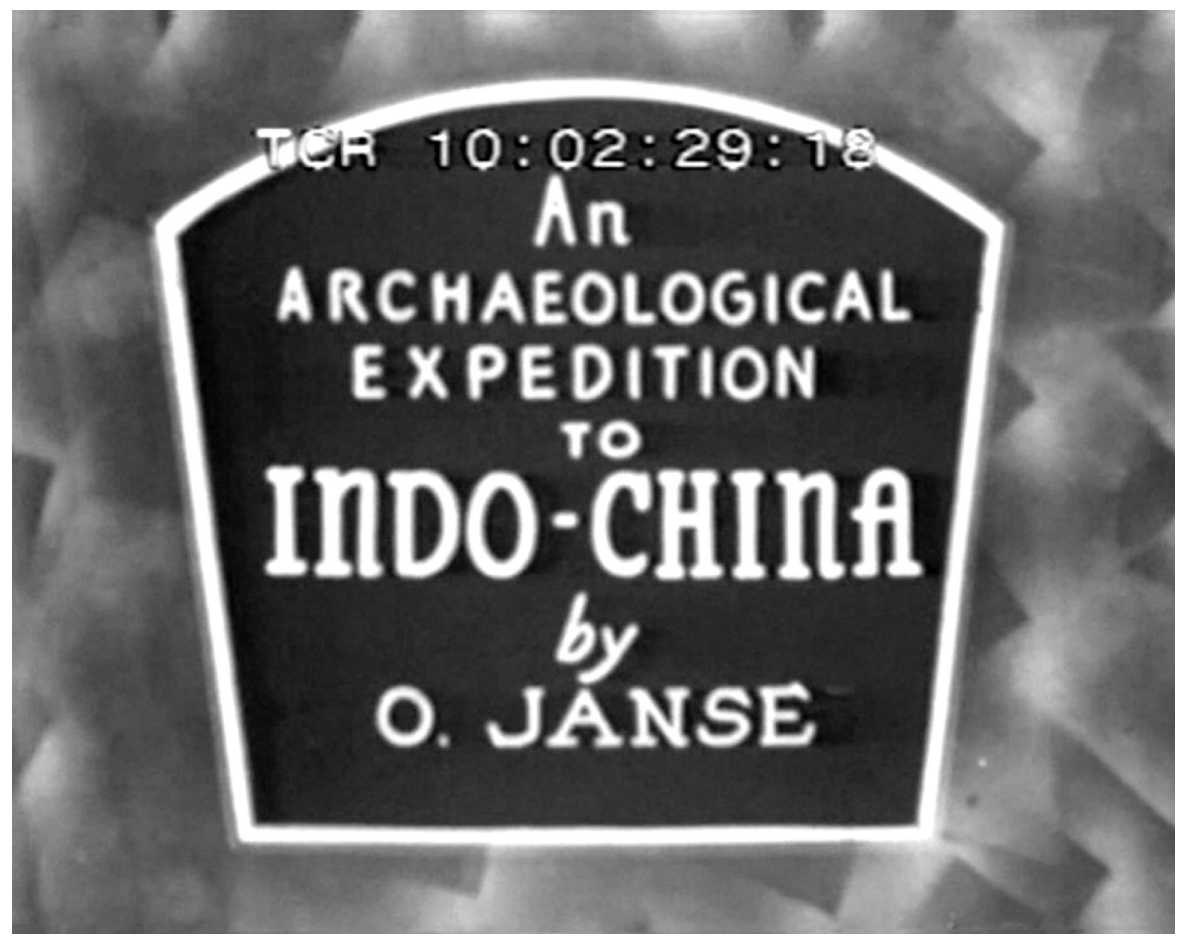

Fig. 65. Introductory title. Still from film, edited by Ray Kellogg at the OSS.

and stops to pose for the camera. A short segment shows the stern of the ship from afar, zooming in on the name Maréchal Joffre. This is followed by a 32 -second section titled "The Native Quarter of Colombo", where native people are seen standing, walking, or pulling rickshaws in narrow streets with small shops and lush gardens. A man in western-style outfit passes by on a bicycle. In contrast to this section is the next, titled "The modern section of Colombo", featuring 25 seconds of the British part of the city. A man in a white, colonial-style suit poses in front of the new town hall (which opened in 1928), Olov and Ronny pose with an umbrella in a park, and there is traffic on a broad, boulevard-style street.

The next six sections feature the journey from Colombo to Saigon, with a stop in Singapore. First 27 seconds "Along the coast to Sumatra and Singapore" with sea views of the Sumatra coastline, then 40 seconds "Approaching Singapore" with views of ships and smaller boats at a distance, followed by 14 seconds titled "The entrance to Singapore" with footage of mangrove. "The powerplant" features 7 seconds of a modern industry complex seen from the passing ship, and "The Archaeological Museum" contains 5 seconds of Ronny and an unknown man standing at the entrance of the Raffles Museum (now the National Museum of Sin- 
gapore). The longest section featuring Singapore is titled "The wharves". This 47-second section features Ronny and two unknown western women posing at a street market with a textile vendor approaching them. Native men transport boxes from a ship on pushcarts, and natives in five canoes, one with a monkey in it, skilfully manoeuvre the strong currents of the harbour. The section from Singapore ends with a frame of a small sailing vessel, seen from a distance.

After more than 5 minutes of film, they arrive in Indochina, with the 59-second section "Up the Saigon River to Saigon". From letters and other documents we know that it was shot on 9 November 1936, and it begins with Ronny posing at the gunwale. Flat green landscape passes behind her and children play on board the ship. A small aeroplane passes close by the ship. They meet a large passenger ship and another aeroplane passes. The landscape is flat but lush, and they pass several smaller ships before the camera is turned to the contours of the city with its characteristic two-tower cathedral appearing at a distance. The section ends when the ship approaches the quay.

The next section, "Tourane (Annam)", is 30 seconds long and features boats and native boat life along the sea, and native Annamite people in characteristic conical hats walking by in the street. "The Cham Museum at Tourane" is a 19-second view of a museum villa from the street, with a native man and a cycle-rickshaw passing by. It is followed by "Native fishing methods at Cua-tung (Annam)", which is one of the longer sections ( 2 minutes and 10 seconds). It features a fishing technique where fish are lured into a creel by means of fencing and beating the water with a certain kind of rope (see fisherman with rope in the chapter on the Indochina expeditions, fig. 50). Three shorter sections follow: "Miss Annam" with 13 seconds featuring a group of native children with particular focus on a small shy-looking girl; "Cua-tung Beach, A summer resort near Hue, Central Annam" with 15 seconds view over a beach with no people; and the 17 second long "Balang Beach in Thanh Hoa", where six natives in conical hats pull a rope from the water and Ronny walks towards the camera surrounded by a group of native children. The first part of the film ends with a 59-second long section titled "Sam-Son Beach, a summer resort in Thanh Hoa, Northern Annam", where naked native boys fish with long sticks and a group of natives in conical hats pull nets. The section ends with footage of natives paddling longboats at a distance, a view resembling the motifs on the Dong Son kettledrums.

The second part of the film begins with a 50 -second section titled 
"Dong-son (Thanh Hoa). Annamese comedians". After a very brief segment with what appears to be a trench for the excavation of pole constructions at Dong Son on the bank of the river Song Ma, and a glance of water buffaloes grazing a rice paddy, the rest is devoted to a village theatre performance with Annamite men in festive gear and groups of children looking into the camera, and an actor performing in elaborate costume with a crowd around him, and smoke produced as part of the setting for the performance. It is followed by "An Annamese procession at Thanh Hoa", which is a 39-second-long view from a balcony or rooftop, of a ritual procession in a broad street, with officials, flags, umbrellas, and two dignitaries in rickshaws. As in the previous section, smoke is produced as part of the setting for the procession.

The following five sections are of Hanoi. The first, "Hanoi (Tonkin) and its flower market" is a 40 -second view of Hanoi street life with traffic police, a native lady in the characteristic Áo dài tunic looking out over the Hoan Kiem Lake (which dominates the old city centre of Hanoi), the flower market with female vendors and buyers, and finally the iconic view of the Ngoc Son temple in the middle of the Hoan Kiem lake. Following that introduction to Hanoi are three short sections: "The Archeological Museum", with 9 seconds of exterior footage of the Musée Louis Finot (now the National History Museum); 7 seconds of "The Doumer Bridge crossing the Red River at Hanoi" with the bridge shot at a distance; and 15 seconds of "The picturesque native quarters of Hanoi" with a view of a street where native people walk and a man in colonial-style garment passes on a bicycle. The Hanoi part ends with a 30 second section titled "The Van Mieu Pagoda (Hanoi), temple of literature". It is set up like a visit to the temple, with a sequence of cuts from the gate through the garden to building facades. Ronny is seen entering one of the buildings in the company of two men (who we believe are the conservator René Mercier and EFEO's director George Cœè̀s), followed by a native woman and a boy in colonial outfit (who may be Cœdès's wife and son).

After the five sections from Hanoi follow thirteen sections featuring tribes in Tonkin (today Northern Vietnam), first with a 39-second-long piece that serves as an introduction to the new mountainous landscape. "Among the Muong and Man tribes at Hoa-binh (Tonkin)" features Ronny and Nguyen Xuan Dong travelling by longboat on a river. They pass a lake with mountains, other longboats and native boats with roofs. A native woman in a boat turns away when she sees the camera. The next section, "The market at Hoabinh is visited by the people of the Man 
Fig. 66. "The market at Hoabinh is visited by the people of the Man tribe". Still from film.

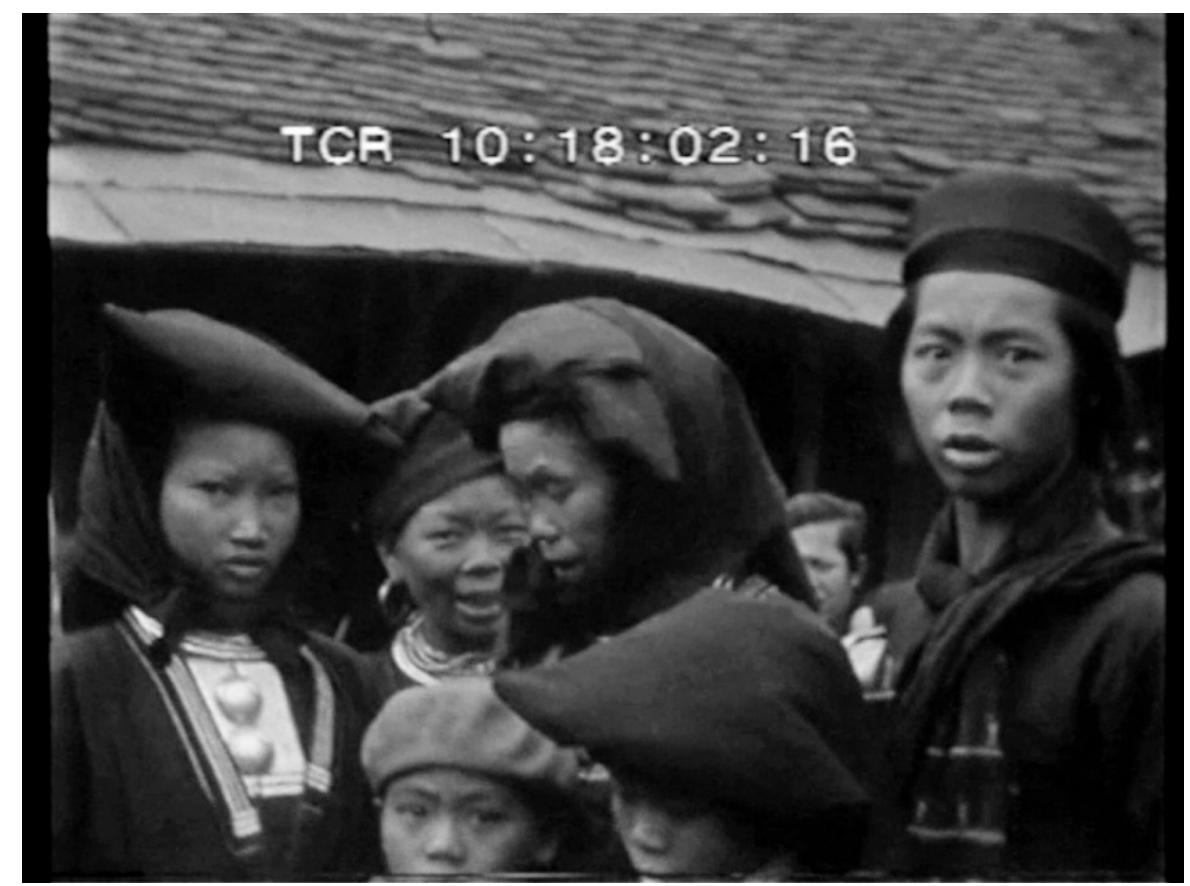

tribe" is 1 minute and 21 seconds long, and features natives of the Man tribe at the market. They are either unknowingly filmed from behind, or arranged by Ronny and Dong in exact poses for the camera. In one sequence they arrange a group with a man, an old woman, a middle-aged woman, a young woman, and children for a group photograph. The section also contains footage of baskets with chicken for sale and boats by the river near the market. "The home of a Muong Chief, at Hoa-Binh, Upper Tonkin" is 37 seconds long and begins with Dong coming out of a house smiling, followed by a group of native people in official clothing, arranged for a group photograph together with Ronny in front of the house. The section ends with a sequence of another native family walking on a dirt road with bags on sticks.

The remaining ten sections featuring tribes in Tonkin were shot in Tinh-tuc, the mining town in the mountainous northern region where Olov and Ronny spent the summer of 1937 in Charles Bastide's villa to escape the heat and stress of the lowlands. The first two sections from Tinh-tuc feature "The wolframite mines and the village of Tinh-tuc (Tonkin)" with a 23 second view over the open mines, and 28 seconds of village life under the title "The only street in the mining village". Another 28-second section with the title "Annamites and Thai mingle 
at the market of Cao-Bang, upper Tonkin" features groups of women at a market, some laughing, apparently embarrassed by the sight of the camera. Six more sections follow, all of which appear to have been shot in Tinh-tuc during the French national holiday on 14 July. The first is 25 seconds with groups of people in ethnic costume and colonial suits with tropical helmets, seen from behind. It is followed by "The greased pole", which is 30 seconds and features a native man attempting to climb a greasy pole, with a crowd around. Two native men in ceremonial gear pose in the front yard of a villa, turning to the side and back for the camera. They are followed by two native children and a woman, posing in a similar fashion in the same villa garden. A short, 12-second section follows: "Dancing Sorcerers of the Man tribe", where a group of musicians and sorcerers in ceremonial gear prepare a performance in the villa garden. In the cuts between frames a colonial-style assistant flashes by, helping to arrange their positions. After that is a 1-minute-long section, "Ritual dances performed by Man-Coc sorcerers at Tinh-tuc" where three sorcerers (as above) bow twice to the camera and start to perform a dance, one of them using cymbals. Three musicians play the traditional khène instrument and some sort of clarinets behind the dancing sorcerers. Two young native girls are watching from the side. Two shorter sections end the part from Tinh-tuc. First 20 seconds with the title "People of the Man-tien Tribe", where two girls in festive gear and one older man pose for the camera, smiling and laughing as they take instruction. They turn anti-clockwise from front to side to back, to front again, with the old man leading the way. And finally, 23 seconds titled "Ritual dances performed by Man-Tien sorcerers at Tinh-tue [sic]", where two men in ritual gear dance with cymbals in front of the same two girls as in the previous section.

The film ends with two sections featuring travels. First a journey by train titled "A trip from Tonkin to Yunnan (Southwestern China)", which is 1 minute and 15 seconds long and shot through the train window of mountainous landscapes, rice paddies and natives at a train station. The final section is 48 seconds from the scenic tourist destination Ha Long Bay: "The Gulf of Along (Tonkin)" with views over water and the iconic limestone karsts. The film ends with Ronny boarding a small covered boat, and some final shots from the boat of the water and limestone karsts. 
So, what did the OSS personnel see when they watched Janse's film in the Administration building in Washington, DC, in June 1944? With its forty sections with subsequent titles, the film assumes the logic of an ethnographic travelogue. It follows an actual geographical route from Marseille in France via Ceylon and Singapore to Saigon in southern Indochina. As it proceeds north through Annam and Tonkin to Yunnan and $\mathrm{Ha}$ Long Bay at the end of the film, it appears to present a range of visual facts about the lands on display. But the perspective it offers is, essentially, a view of Indochina and Ceylon through the eyes of the travelling colonizer.

Three main themes are accentuated in the film: native techniques (transport and subsistence), colonial infrastructure (industry, architecture and transport), and visual characteristics of ethnic groups (physical form and clothing). Most parts of the film were shot during the second overseas journey with the Maréchal Joffre, and the summer months they spent in Tinh-tuc, in Charles Bastide's villa by the tin and wolfram mines. Considering that the film is presented as "An Archaeological Expedition to Indo-China", it contains surprisingly little archaeological information. Archaeological museums are featured only as building exteriors, and a few seconds of an excavation trench, probably at Dong Son, swish by on one occasion. Archaeology seems here to be most valuable as a framework that gives a sense of purpose to the travelogue and authority to the eye of the camera.

The forty film sections feature people in colonial-style garments and tropical helmets travelling in modern vehicles and using advanced equipment, clearly divided from natives in primitive clothing or elaborate ethnic costume, using rudimentary techniques and simple means of transport. Natives are featured either in the process of doing practical everyday chores such as fishing, rowing, or digging, or they perform rituals. They are often seen posing for classic ethnographic documentation photos, from the front, side, and back. The colonizers smile and socialize, and assist the photographer to arrange the native objects in the most favourable positions and angles for the camera. Hence the colonizers are often found behind or beside the lens, creating a sense of belonging for the eye of the camera. The natives are always found in front of, never actively behind or beside the camera.

The two groups are not, however, entirely distinct in terms of race or ethnicity. Natives occur in a number of different groups, from Ceylon to Indochina. The outfits and social poses of the colonizer are sported not 
only by the French and the British, but also by Annamite and other native functionaries such as Janse's colleague Dong.

Pace is a key to the creation of distinct images that differentiate natives from colonizers. While the colonizers move, walk and travel fast with a sense of purpose to their movements, the natives use slow and primitive vehicles, walk slowly by, and are often featured sitting or standing still. Pace works here through the medium of the moving image, with the same effect as the contrasting words describing native and colonial societies in Janse's memoirs Ljusmannens gåta. ${ }^{877}$ It portrays and accentuates a developmental difference between natives and colonizers, which in turn demonstrates the necessity and righteousness of the French mission civilisatrice and other imperialist interventions by Western powers.

\section{The reports}

One of the few things we know for certain about Olov Janse's time at the OSS and US State Department is that he worked with issues concerning Indochina. The situation in Indochina after the Japanese occupation in September 1940 was complicated. ${ }^{878}$ The forty-two thousand French colons suffered from the brutal Japanese methods of occupation, as did the twenty-three million native inhabitants. But the French colonial policy remained intact, and France had no intention other than to restore Indochina as a French territory after the war.

In Indochina, however, several movements for independence were gaining ground. One of these movements was the communist Viet Minh, led by a man called Nguyen Ai Quoc (literally: He Who Loves His Country) who in 1942 changed his name to Ho Chi Minh (He Who Enlightens). ${ }^{879}$ Ho was the son of a Confucian scholar and teacher, and as a young man he travelled across the seas to France, the United States, and the $\mathrm{UK}$, working as a kitchen assistant on passenger ships. He was almost exactly the same age as Olov Janse, ${ }^{880}$ and they could very well have met in Paris in the early 1920s, "in the cafés of Montmartre, where everyone

877. See the chapter "Euphoria".

878. The section on Ho Chi Minh and the wartime situation in Indochina is based on the works of Logevall 2012; Tønnesson 2010; and Smith 2005 :chapter 10.

879 . He used around seventy different pseudonyms over his lifetime, often with potent political connotations indicating his current mission and ambition.

880 . His official year of birth was 1890 , but some sources claim that he was in fact born in 1892. See Logevall 2012:4n5. 
debated everything". ${ }^{81}$ They were also similar in some senses; the slight and slender Vietnamese with sharp eyes and piercing intellect, and the tall pale Swede with the grand gestures of an aspiring cosmopolitan. They were both strangers in Paris, but they were hommes de lettres and spoke several languages. Both have been described as charming and sensitive, with confidence-winning personalities. ${ }^{882}$ However, if the socialist sentiments of Janse's Ture-Nerman-inspired teenage years had started to fade by the early 1920s, Ho's socialist political interest was awakened during his years in Paris, 1919-1923. Already in the years following the First World War, when he had joined a group of Vietnamese nationalists in Paris, he had approached a United States delegate with a request for support to end French colonial rule in Indochina. On his journey round the world he had spent some time working in Boston and New York City, and was much attracted to the ideals of the US Constitution. In Paris, however, the US leaders did not respond to his call for support. Ho (then Nguyen Ai Quoc), who had already experienced the ambiguities of the French Empire, and seen with his own eyes how the fine liberal ideals of liberté, égalité, et fraternité had been used to gloss over oppressive or violent situations of colonial reality, realized that he could not count on steadfast support from the United States, despite their fine ideals and official anti-colonial policy. Instead he continued to search for support for his independence mission among socialist and communist groups in France, the Soviet Union and China, before he returned to Indochina in 1941 to lead the Viet Minh independence movement.

When the United States became involved in Indochina through the OS S during the Second World War, the Viet Minh movement was gathering momentum. The main objective for the OSS involvement in Indochina was to put an end to Japanese occupation. But the United States and President Roosevelt also maintained a strong policy against colonialism, and were therefore bound to support native movements for independence. It annoyed their French and British allies, who were obviously for the reinstitution of colonial rule, and it also complicated the intelligence relations with China. The US position was moreover complicated by the fact that Viet Minh was a communist organization, which was not compatible with US agendas. But the anti-imperialist policy eventually overruled all complications, and the OSS officers in Indochina came to

881. Logevall 2012:15.

882. Logevall 2012:15. 
offer direct support to Ho Chi Minh and the Viet Minh. The Viet Minh were given arms and military training by the OSS, and on one occasion in July 1945 it has been claimed that the OSS medic Paul Hoagland saved Ho's life in a small village northwest of Hanoi, by treating him for malaria, dysentery, and a variety of other diseases. ${ }^{883}$

Interestingly, Olov Janse's personal sentiments were quite different from OSS's official policy. He was a devoted Francophile, and saw no better future for Indochina than to be reunited with the French Empire after the war. With Ronny's family history in the Soviet Union he had also reason to question the benefits of state communism.

Janse wrote three reports for the OSS; Some methods of Japanese penetration in French Indo-China previous to the war in 1943; The Peoples of French Indochina (published by the Smithsonian Institution) in 1944; and a Joint Army-Navy Intelligence Study of Indochina: People and Government in $1945 .{ }^{884}$ The first appears to have been written for MO (Morale Operations) purposes, immediately after he joined the OSS in August 1943. It takes the form of an "Interoffice memo", and contains information about Cao Dai - a religious movement established in southern Indochina in 1926, whose leader had criticized the French colonial regime and been actively engaged in anti-French politics - as a means for Japanese infiltration in the area before the occupation in 1941. Compared with the other two reports, this one is written in first person and has a tone of personal reflection: "My attention was first called to ...", ${ }^{85}$ " a French customs employee stationed in central Annam, where I was carrying out archaeological fieldwork, told me that ...", ${ }^{86}$ and so on. Moreover, it offers a number of assumptions which are not properly grounded: "it can probably be assumed that he was acting as a Japanese agent" ${ }^{887}$ and "Communists in Indo-China are also said to have used sorcerers as secret agents". ${ }^{888}$ In response to these assumptions Janse finally presents a number of ideas and suggestions for Morale Operations to keep the native population of Indochina positive towards the Allies: "As almost all schools in Cambodia and Laos are in the hands of the bonzes, it is important to secure in them a friendly

883. Smith 2005:306.

884. Janse 1943; Janse 1944b; Janse 1945 (with an attributed copy at the National Library of Sweden (Swe: Kungliga biblioteket), Stockholm (22 A d Fol.)).

885. Janse 1943:1.

886. Janse 1943:2.

887. Janse 1943:4.

888. Janse 1943: Appendix III 
attitude toward the Allied Nations, and to arouse antagonism toward the Japanese", 889 and "the Man [ethnic group] used signal drums to send secret messages to their kinsmen, widely scattered in the inaccessible mountainous region. [...] It is possible that such a system of signaling could be improved and used in these regions by the Allies for sending secret messages and spreading rumours." 890

The latter two reports are of a different character. They are written in a more detached and scholarly language, and contain no creative suggestions or overt guesses, which is why we believe they can both be attributed to the R\&A rather than the $\mathrm{MO}$ branch. They are partly overlapping, and the first - The Peoples of French Indochina - was one in a series of booklets produced by the Smithsonian Institution, each with its own author, that together cover a large part of Southeast Asia and the Pacific. ${ }^{891}$ Initially Janse's part takes the form of a travel guide introduction, covering geography, climate, geology, economy, and so forth. Compared with the other booklets in the same series, and as indicated by the title, Janse has a particularly strong focus on the native population of Indochina. $\mathrm{He}$ describes the different tribes and ethnic groups with their history, language, customs, and physical appearance. These descriptions are almost identical to the descriptions of native people in the third report, which was published a year later.

Of the texts Janse wrote for the Harvard Defense Group and the OSS, the last one, the Joint Army-Navy Intelligence Study of Indochina from 1945, is the most elaborate and the most interesting. It is 36 pages long and divided into eight chapters:

100. General description and historic setting ( $\left.\mathrm{p}_{1-5}\right)$

101. Size and distribution of population (p $5-8)$

102. Physical and cultural characteristics ( $\mathrm{p} 8-19$ )

103. Educational and cultural institutions and agencies ( $\mathrm{p} 20-22)$

104. Labor (p 22-24)

105. Government ( $\mathrm{p} 26-34)$

106. Political attitudes (p $35-36)$

107. Principal sources ( $\left.\mathrm{p}_{3} 6\right)$

889. Janse 1943: Appendix II.

890. Janse 1943: Appendix V.

891. Price 2008:96. 
It was submitted when Janse was Deputy Chief of the South-East Asia section of the Research and Analysis Branch of the US State Department, and can in most parts be read as a companion piece to the film he produced for the OSS. If they were read and watched in tandem (which we can assume they were), the report offered details and profound analysis, while the film added context and a sense of reality to the account. And just like the film, the report could be described as a piece of pro-colonial propaganda masquerading as a rather dry account of facts and details:

\section{Relationships between local French and native peoples.}

Before World War I Indochina did not attract French administrative personnel of the highest calibre. The recruiting of high-grade officials was hampered, partly because of the bad reputation of Indochina's climate and the distance from France. Officials sent out to Indochina did not all have adequate training and high moral standards. As a result numerous serious conflicts arose between the French and the local population. The attitudes of French officials and private individuals were criticized by local and outside observers.

After World War I the situation improved considerably. A government-sponsored Colonial School under the guidance of highly qualified teachers was established in Paris to train personnel designated for overseas duty. In recent years the French have shown more respect for native customs and systems of justice, and have given the local peoples a greater share in administration.

In spite of criticism of the French in Indochina - from French, native, and outside sources - their Indochinese administration can be credited with creating an educational system adapted to local conditions, extending free medical care, improving public hygiene, abolishing slavery, constructing roads and railroads, repressing lawlessness, introducing labor laws, and preserving historical monuments. ${ }^{892}$

\section{Preservation of village organization.}

In most areas the village was the basic unit of administration. There the ancient forms of political and social control had been preserved and maintained. ${ }^{893}$

892. Janse $1945: 19$.

893. Janse 1945:27. 
Local Annamite administration. The village was the basic unit of local Annamite administration. The village was a kind of local state, jealous of its independence and stubbornly adhering to its own traditions and responsibilities. The French interfered very little with this traditional popular unit of government. ${ }^{894}$

\section{Japanese occupation of Indochina.}

Throughout this five-year period [1940-1945] the Japanese encouraged anti-foreignism and nationalism with the result that the Kings of Annam, Laos, and Cambodge recently have declared their "independence".

The fall of France in 1940 left Indochina in a precarious and virtually helpless position. ${ }^{895}$

France and the French colonial administration are described in positive words that signal progress, courtesy, and benevolence. If mistakes have been made, they have been corrected, thoughtfully and respectfully visà-vis native interests. In contrast to the French development and progress we have the village organization, which is described as an ancient and primitive form of administration - either stubbornly independent, or in need of French protection to be preserved and maintained. The Japanese presence and the subsequent declaration of "independence" by the Kings of Annam, Laos and Cambodia - with quotation marks to emphasize the impossibility or absurdity of the claim - is described in metaphoric terms as an assault on a helpless child who has lost the protection of her parents.

Religion is another theme described in starkly polarized terms. Descriptions of Christian interventions are characterized by positive words and judgements:

Catholic missions have been active in Indochina since 1815 and have met with considerable success. Converts now number between 1,500,000 and 2,000,000. [...] Educational, medical and social services as well as religious teaching have had considerable effect on the people, particularly in Annam. ${ }^{896}$

894. Janse 1945:30.

895. Janse 1945:5.

896. Janse $1945: 4$. 
... whereas the popular Caodaist movement is described as a threatening and deceitful sect:

Caodaism, sometimes called neo-Buddhism, is a politico-religious cult which professes to unify several religious systems. It was introduced into Indochina about 1924, probably with Japanese backing. [...] French authorities took measures to repress the movement and check its spread. In 1941, however, between 1 and 2 million people throughout southern Indochina reputedly were members of the sect. The Caodaist organization was used as a propaganda agent by the Japanese to combat French influence and to prepare the country for invasion. ${ }^{897}$

The people of Indochina are described in this report, and in the 1944 booklet, in racist and biologistic terms and with the sexualized discourse surrounding native women that is typical of French colonial texts: ${ }^{898}$

102. Physical and Cultural Characteristics. A. General factors.

The population of Indochina is composed of a great variety of peoples and tribes, each of which with its own language and customs. For many centuries Indochina has been a meeting place of peoples and cultural currents. The earliest settlers probably were negritos who were subsequently absorbed or driven out by Indonesians (also called Proto-Malays, Moi, etc., presumably of Caucasid affinities). Finally a Mongoloid element arrived, and mingled with the former settlers or pushed them into the remote mountains.

It is possible today to distinguish two chief physical types, though there is great individual variation. The Indonesian strain, in general, is short in stature, long-headed, with light or lightbrown skin, moderately broad nose, straight of wavy hair, and eyes set straight. The Chams are representatives of this group. The second and much more numerous type is the Southern Mongoloid $[\ldots]$ The Annamites and the Thai are considered as belonging to this stock. [...]

897. Janse 1945:4.

898.E.g. Norindr 1996. 
The impact of Chinese culture is clearly apparent in the northern and eastern parts of Indochina, while Hindu civilization spread in the west, especially in Cambodge. In recent years the population in urban centres, particularly the Annamites, has shown rapid adaptation to European culture. ${ }^{899}$

The region of Hue in central Annam is famed for the beauty and grace of its women, as well as for their aptitude for the fine arts.

In his behavior the average Annamite is reserved, cautious, and ceremonious. Generally he is capable of great self control, and does not display his feelings ostentatiously. He reacts strongly against those who antagonize him, especially by vulgar and brutal manners. He has a certain sense of humour, and tends to catch and capitalize the ridiculous. In general, he thoroughly dislikes irascible persons, and does not appreciate the back-slapping type of familiarity. .00

In the mountainous interior of Indochina there are a number of primitive tribes, partly nomadic, partly settled. [...] About $75 \%$ of all the mountain tribes in northern Indochina belong to the Thai group. [...] In many cases, they have been influenced strongly by their more highly developed neighbors. ${ }^{901}$

[About the Moï] In recent years the French administration made a great effort to civilize these backward and nomadic tribes and to have them settle as farmers and cattle-breeders. A few have been converted to Christianity by French and American missionaries..$^{902}$

A common figure in the accounts of the reports and the film is that of cultural development through influence. This common figure, which is a crucial justification for the entire French Empire, is illustrated historically by the name "Indo-China". Emphasized by the hyphen, as in the French Indo-Chine before 1900, and in American accounts throughout the twentieth century, is the identity of this landmass as the historical meeting of

\footnotetext{
899. Janse $1945: 8$.

900. Janse 1945:11.

901. Janse 1945:15.

902. Janse 1945:17.
} 
two great cultures: that of India and China. Janse continues the tradition of describing Indochina, or "Indo-China", as the historical meeting place of two great civilizations. By implication, the native peoples of Indochina are either stagnant in their primitivity, or have developed historically by influence of more advanced neighbours. The slightness of their own cultural importance is demonstrated by the minuscule hyphen between the two important civilizations. Hence they must wait for new influences from culturally advanced centres (such as France or the United States) to continue developing.

As a final piece of advice for Allied forces landing in Indochina, Janse writes:

\section{The attitude of the Indochinese toward an Allied landing.}

Because the Indochinese are a complex of peoples living on different cultural levels and possessing different degrees of political sophistication, their response to Axis and Allied appeals has varied greatly. [...] Some Annamites have been hostile to both the French and the Japanese; some have been passive before both; some have sought the favour of the one or the other. Allied airmen shot down in Indochina could never be sure whether the Annamites would turn them over to the French or to the Japanese. Most Indochinese villagers want only to avoid trouble and will therefore support the winning side. Probably most of the politically minded Indochinese prefer the French to the Japanese and, foreseeing that the restoration of French authority in Indochina is inevitable, will therefore assist, or at least not impede, Allied moves. ${ }^{903}$

We don't know what impact these texts and the film produced by Janse had, if any at all. From his Francophile position, Janse believed that the Japanese would eventually be thrown out and that the French would return and continue the work for development and civilization in the region. The peoples of Indochina would reach "a new post-war status, aiming toward their gradual emancipation within the framework of the French empire". ${ }^{904}$ This is a statement clearly contradicting President

903. Janse 1945:36.

904. Janse 1944:27. 
Roosevelt's anti-colonial policy,905 and must have been quite controversial in the OSS and the US Department of State.

Much smoother in relation to US policy was the image he presented of Indochina as a region with people in need of civilized help (to develop into modernity) and protection (of their monuments and traditions). If anything it was this image, presented with subtle choices of words and perspectives - connotations and metaphors, of pace, stillness, and movement - that would influence the OS S officers. If they watched Janse's film and read his reports, this image ought to have formed their expectations and calibrated their gaze prior to any real engagement with the land and the people of Indochina.

We see here clearly the development of a strong new theme in Janse's professional profile, which could be discussed in terms of public diplomacy. Public diplomacy has emerged as an important field of political historical research over the past few decades, and has focused largely on the soft politics of the United States. ${ }^{906}$ According to Nicholas J. Cull public diplomacy can be understood as "an international actor's attempt to conduct its foreign policy by engaging with foreign publics". 907 It can also be described in words such as "cultural diplomacy", "diplomacy of ideas", "soft diplomacy", "heritage diplomacy" and so on. But in most cases it falls under Cull's definition. An oft-cited example of public diplomacy is the US international broadcasting agency Voice of America, which was established in 1942..$^{908}$ This form of diplomacy has been in use for a very long time, and is not restricted to the US administration, although the term "public diplomacy" was coined in 1965 , and most of the research on public diplomacy has focused on the United States. ${ }^{909}$

Frank Ninkovich sees the origin and background to public diplomacy in an early twentieth-century philanthropical context. ${ }^{910}$ Its original purpose was, according to Ninkovich, to prevent future wars. It was based

905. E.g. Smith 2005 .

906.E.g. Dizard 2004; Cull 2008.

907. Cull 2008:xv, see also Osgood \& Etheridge 2010 for a definition of the concept. 908. Olov Janse spoke about Vietnam on Voice of America in July 1959.

909. Cull 2008:xv.

910. Ninkovich 1981, see also Dizard Jr. 2004 regarding the United States Information Agency (USIA). 
on the idea that wars were the consequence of lack of education, lack of civilization, and what could more generally be described as a lack of a gentleman's approach to the world. The philanthropical projects of education and civilization that were aimed at preventing war are in Ninkovich's view the origin of public diplomacy.

Although the research field of public diplomacy has been largely restricted to the public information politics of post-war United States, and Ninkovich traces the ideas further back to the early twentieth-century philanthropic era, it is possible to find much deeper roots to this phenomenon. The connection with the "soft politics" and civilizing missions of French and British colonial empires seems obvious, ${ }^{911}$ and the ideological foundation of this discourse can in turn can be traced back to the Enlightenment and the German philosopher Immanuel Kant (1724-1804). Here we would single out two of his essays - Answering the Question: What Is Enlightenment? from 1784, ${ }^{912}$ and Perpetual Peace: A Philosophical Sketch from $1795^{913}$ - which laid the foundation for future public diplomacy.

The first essay describes how man can become free, what freedom actually is and what responsibilities such freedom demands. The second essay underlines how states should act upon each other. Of particular interest here is Kant's argument that only states with similar systems can be included in this definition of the state and of "man", and it goes without saying that he refers mostly to European states. This implies that states and human beings outside these systems are not included in Kant's definition at all and can be treated in any way, because they lack the fundamental rights bestowed on humans and states inside the system. As a consequence of Kant's definition, the outsiders are not civilized, they lack education, and they do not behave according to the rules of the gentleman.

Part of the definition of the gentleman, moreover, is his willingness to educate and include others in his system. If everyone spoke the same language and shared the same ideas, there would be eternal peace, is Kant's fundamental idea. And this idea serves as the ideological foundation and justification for public diplomacy to this day. It is true that since the Second World War, such strategies of soft politics have been developed in the United States, but it has long and winding ideological roots leading

911. E.g. McClintock 1995; Norindr 1996.

912. German original: Beantwortung der Frage: Was ist Aufklärung?

913. German original: Zum ewigen Frieden: Ein philosophischer Entwurf. 
all the way back to Kant. But there is reason for concern, because if, as it was for Kant, everyone or everything that exists outside the parameters of one's own system is merely an Other with no rights, how shall that Other be understood and dealt with? Many solutions have been offered to this question since Kant's days: colonial racism, wars, exploitation, development programmes, missionary campaigns and public diplomacy. The overall aim of all these different actions has been to change and if needed force the Other into the system, to educate him, make him civilized, and turn him into a gentleman; often in the name of peace and benevolence. Let us bear this in mind when we follow Olov Janse through the following chapters.

For Olov and Ronny Janse, the years in exile working for the OSS and the US Department of State meant the beginning of a new phase in their lives and careers. For Olov it was a definitive turn away from archaeological research towards a life as civil servant in the highest levels of national and international bureaucracy. The world was about to change again, and Indochina would soon be at the centre of attention for US foreign policy. 